\title{
A comparative study on CSR disclosure between Indonesian Islamic banks and conventional banks: the application of GRI and ISR indexes
}

\author{
Rizki Hamdani*, Yunan Najamuddin, Padma Dwi Haryanto, Muamar Nur Kholid \\ Department of Accounting, Universitas Islam Indonesia, Yogyakarta, Indonesia \\ Corresponding author email: rizki.hamdani@uii.ac.id
}

\section{A R T I C LE I N F O}

\section{Article history:}

Available online

\section{Keywords:}

CSR disclosure, GRI Index, ISR

Index, Islamic banks, conventional

banks

DOI:

https://doi.org/10.20885/jaai.vol24.i $\underline{\text { ss2.art8 }}$

\author{
A B S T R A C T
}

This study aims to determine whether or not there is a discrepancy in Corporate Social Responsibility (CSR) disclosure between sharia and conventional banks in Indonesia, and which CSR aspects are better between those two types of the banks. This study applied a quantitative approach. The analysis method used in this study to test the hypothesis was independent sample t-test. The method was applied to determine whether there is a significant difference in the average value between sharia and conventional banks. The number of samples in this study were 40 consisting of 20 Islamic banks and 20 conventional banks. The data taken were those between 2011 and 2014 which contained the information related to CSR. The results of this study indicated that there were significant differences in CSR disclosure between sharia and conventional banks. On average, CSR disclosure rate of sharia banks was higher than that of conventional banks. The weaknesses of CSR disclosure of sharia banks were in the aspects of environment and general information, while the weaknesses of CSR disclosure of conventional banks were in the aspects of energy, health and safety of the employee, product, and society involvement. Due to the limitation of this study in compiling the aspects of variables presented in Global Reporting Initiative (GRI) and Islamic Social Reporting (ISR), it is suggested for the future study to do further detail analysis to compile and to combine with the primary data in order to get the precise quality of the data disclosed by each bank.

\section{Introduction}

The basic idea of Corporate Social Responsibility (CSR) refers to the obligation of businessmen to run their business in line with the values and objectives to be achieved by the communities in which they operate (Bowen, 1953). In the process of making profit, companies often cause environmental damage or other social impacts. In addition, different types of stakeholders in one bank entity may affect the expectations and compensation to be obtained by the company (Yamak \& Süer, 2005). CSR practices are mostly done by mining companies and manufacture companies which are categorized as high-profile corporates. Viewing from the previous study, developed countries provide more significant CSR disclosure than developing countries (Bhatia \& Makkar, 2019). However, in line with the global trend of CSR practices, banking industry has also been implementing and reporting the practices of social responsibility in the annual report though in a relatively simple form. The disclosure is not only done by conventional banking but also by sharia banking (Fitria \& Hartanti, 2010).

In Indonesia, sharia banking is one of the fastest growing industries. A survey by Bahrain Monetary Agency in 2004 showed the number of sharia banking institutions which rose significantly from 176 in 1997 to 267 in 2004 and operated in 60 countries worldwide (Zaher \& Hassan, 2001). With a growth rate of $15 \%$ per year, sharia banking industry happens to be the fastest growing sector in Muslim countries. In Indonesia, although sharia banking is recorded to grow significantly, compared to conventional banking, the market share of sharia banking is relatively small, at 2.2\%. However, the prospect of sharia industry in the future is believed to be better and reckoned.

Indonesian regulations concerning CSR is stipulated in Acts of Incorporated Company No. 40 of 2007 Article 74 Verse 1 and in the Acts No. 25 of 2007 on Capital Investment. Following those Acts, there are plenty of companies conducting CSR as the result of the global trend which encourages companies to take social responsibility towards the business environment where the company resides. Therefore, recent banking industries, both conventional and sharia banks, have conducted CSR. Some theories including Agency Theory, Stakeholder Theory, Legitimacy Theory, Political Economy Theory, Accountability Theory, and Institutional Theory have been applied to justify the rationales why or why not companies disclose their CSR information (Deegan, 2002; Deegan \& Blomquist, 2006; Gray et al., 1995a, 1995b; Guthrie \& Parker, 1989; Ness \& Mirza, 1991). However, the 
previously mentioned theories are mostly developed in the context of western market economy which is different from Islamic business context, in both cultural and purpose and ethical (Aribi \& Gao, 2010).

Global Reporting Initiative Index (GRI) and the Islamic Social Reporting Index (ISR) are the references and benchmarks for the performance of CSR implementation. The ISR Index is a benchmark to measure the performance of sharia banking that contains a compilation of CSR standards established by AAOIFI (Accounting and Auditing Organization for Islamic Financial Institutions). The standards are developed further by the researchers especially regarding CSR items that should be disclosed by an Islamic entity. Therefore, the form and format of sustainability reporting vary based on the needs of the organization (Fitria \& Hartanti, 2010). Chintaman (2014) examines the CSR activities of Islamic and conventional banks in Gulf Cooperation Council (GCC) area and has found that Islamic banks are more innovative in carrying out various types of CSR activities, while conventional banks are more likely to organize CSR disclosure programs. El-Halaby and Hussainey (2015) find that the level of CSR disclosure by Islamic banks worldwide is very low.

Numerous studies have investigated CSR disclosure applied in Islamic business (i.e. Aribi \& Gao, 2010; Haniffa \& Hudaib, 2007; Hassan \& Harahap, 2010; Maali, Bassam, Casson, \& Napier, 2006; Chintaman, 2014; Nobanee \& Ellili, 2016). The purpose of this study is to test which aspects of CSR are better, between sharia and conventional banks in Indonesia by compiling the aspects of variables in GRI and ISR index. This study is to show which CSR disclosure is better between conventional banks and Islamic banks. Empirically, this research can be used as a basis for policy making by the management and investors, especially as a material for consideration in policy making in connection with the implementation of CSR in company operations and its disclosure in the company's annual report.

\section{Literature Review}

\section{CSR in Conventional Concept}

From a conventional perspective, there are several theories behind the implementation of CSR in a company, namely Capitalism Theory, Social Contract Theory, Instrument Theory, Legitimation Theory, and Stakeholder Theory. According to Friedman (1962), if a company does CSR activities outside the interests of its shareholders, it will violate the company's goals. The only obligation of a company including its CSR programs is to give prosperity to the shareholders. Donation activities are allowed if they are deemed to benefit the companies and not just as philanthropic activities.

According to Moir (2001), a company can only do well if it is supported by the surrounding community. Thus, in the case that the company wants to be regarded as a social institution, it must contribute to its social environment. Public perception on the organization is very important and can affect its survival if it violates the social contract that has been agreed (Dusuki, 2008). If the community is not satisfied with the operating company, the community will effectively withdraw the contract (Davies, 1997). Consequently, to be regarded as a social institution, a company must contribute to its social environment. Social Contract Theory states that business and society are equal partners. Each of them has its rights and responsibilities, directly and indirectly, because the company and society need each other (Dusuki, 2008).

CSR is considered as a tool to achieve the company goals. The proponents of this theory argue that businesses can choose several social programs for good public relations reasons, such as competitive advantage or other strategic reasons without leaving the interests of the main stakeholders, i.e. shareholders. The maintenance of a good corporate reputation through CSR initiatives can add reputational capital, where the company may be profitable in the long run because market forces provide financial incentives for socially responsible behaviour (Burke \& Logsdon, 1996; Fombrun et al., 2000; Garriga \& Melé, 2004; Greenfield, 2004; Husted, 2003; Johnson, 2003; Lantos, 2001, 2002; Quester \& Thompson, 2001; Windsor, 2001).

An important issue that supports the need to generate business reviews in the company management report is whether or not the reviews provide legitimacy for organizational activity (Williamson \& Lynch-Wood, 2008). In legitimacy theory, corporate social responsibility is one way to gain legitimacy from all stakeholders, the higher the level of disclosure of a company's corporate social responsibility, the higher the company's reputation in the eyes of the community (Faradisty et al., 2019). Beetham (2013) points out that legitimacy is multidimensional and involves the justified distribution of power use. He argues that all power systems can be legitimized if: (a) it is in accordance with the prescribed rules; (b) it refers to the mutual belief of both dominant and subordinate; and (c) there is evidence of consent by the subordinate to a particular power relationship. According to Deegan (2002), the company will carry out CSR activities due to social, political, and economic pressures from the outside of the company. Hence, the company will balance these demands by doing what the community wants and what the rules require. This theory is based on the idea that business operates in society through social contracts in which an agreement is made to undertake socially desirable actions in return for approval of its purpose (Guthrie \& Parker, 1989). 
Stakeholder Theory is an attempt to broaden the perception that there is only one dominant interest in public corporates, that is, shareholders (Dusuki, 2008). CSR activities are conducted to accommodate the needs of stakeholders so that the corporate can move well with all stakeholders' supports (Clarkson, 1995). According to this approach, taking into account the needs and rights of all stakeholders in business is a useful way to develop socially responsible behaviors by managers (Maignan \& Ferrell, 2004). The purpose of Stakeholder Theory is to create awareness and responsibility within an organization towards stakeholders; therefore, social reporting helps in managing the interests of different stakeholders (Al-Shamali et al., 2013).

\section{CSR in Islamic Value Concepts}

Islam provides a complete concept of life directing every phase of human life including politics, law, business, and justice in social life (Rice, 1999). While sharia is a system of ethics and values covering all aspects of human life including personal, social, political, economic, and intellectual aspects as well as the mechanisms that are significant to adjust ourselves to a change (Albaity \& Ahmad, 2008). The influence of Islam on the daily activities of society and business is well documented in the Qur'an and Sunnah. Islam is not only a personal religion but also an organization for society and its institutions, as well as a guidance for individual behavior in institutions and social contexts (Tinker, 2004). Many Islamic business values are part of CSR core activities. As shown in Table 1. for example, the main source of social responsibility and business ethics in Islam is majority based on the Qur'an and Sunnah. In relation to this, it is normal that the implementation of sharia law becomes the foundation of various companies, especially sharia banks.

Table 1. CSR and business ethics based on Al-Qur'an and Sunnah

\begin{tabular}{|c|c|}
\hline Some examples of business ethic principles in Islam & Related business practice \\
\hline $\begin{array}{l}\text { The Holy Prophet said "I will be foe to three types of persons on the } \\
\text { day of judgment, one of them being the one who, when he employs } \\
\text { a person that has accomplished his duty, does not give him his due" } \\
\text { (Al Bukhari, No. 2109) }\end{array}$ & $\begin{array}{l}\text { Employee fair treatment, equal opportunity and } \\
\text { non-discriminatory behaviour }\end{array}$ \\
\hline $\begin{array}{l}\text { No Arab has superiority over a non-Arab and no non-Arab has any } \\
\text { superiority over an Arab; no dark person has superiority over a } \\
\text { white person and no white person has superiority over a dark } \\
\text { person. The criterion of honour in the sight of God is righteousness } \\
\text { and honest living (saying of Prophet Muhammad) (Sallam \& Hanafy, } \\
\text { 1988) }\end{array}$ & $\begin{array}{l}\text { Equal opportunity and non-discriminatory behavior } \\
\text { in hiring, buying, and selling }\end{array}$ \\
\hline $\begin{array}{l}\text { God likes that when someone does anything, it must be done } \\
\text { perfectly well (saying of the Prophet Muhammad-pray and peace be } \\
\text { upon him) (Sallam \& Hanafy, 1988) }\end{array}$ & Excellence and quality of work \\
\hline $\begin{array}{l}\text { God does command you to render back your trusts to whom they } \\
\text { are due (Quran 4:54) }\end{array}$ & $\begin{array}{l}\text { Fulfilling obligations and trust in business } \\
\text { relationships and workplace }\end{array}$ \\
\hline $\begin{array}{l}\text { "Give just measure and weight, nor withhold from the people the } \\
\text { things that are their due[.. .]" (Qur'an 11:85) }\end{array}$ & Give full measure and weight \\
\hline $\begin{array}{l}\text { "He who cheats is not one of us" (saying of Prophet Mohamed-pray } \\
\text { and peace be upon him) (Keller, 1994) }\end{array}$ & $\begin{array}{l}\text { Whoever knows of defect in something is obliged } \\
\text { to disclose it }\end{array}$ \\
\hline $\begin{array}{l}\text { "[... .] do not outbid one another in order to raise the price, fairness } \\
\text { in contract negotiation [...] don't enter into a transaction when other } \\
\text { has already entered into that transaction and be as brothers one to } \\
\text { another" (saying of Prophet Mohamed-pray and peace be upon him) }\end{array}$ & Fairness in contract negotiation \\
\hline $\begin{array}{l}\text { The acquisition of knowledge is a duty incumbent on every Muslim, } \\
\text { male and female (saying of Prophet Muhammad-pray and peace be } \\
\text { upon him) (Sallam \& Hanafy, 1988) }\end{array}$ & $\begin{array}{l}\text { Importance of knowledge seeking, research and } \\
\text { development, scientific activities, as well as training } \\
\text { programme }\end{array}$ \\
\hline
\end{tabular}

Social responsibility from an Islamic perspective is derived from the principles that are contained in the Qur'an. Furthermore, Farook (2007) states the three principles underlying social responsibility in Islam, namely; vicegerency, divine accountability, and enjoining good and forbidding evil. The explanation according to Farook (2007) pp. 33-34, are as follows:

a. Vicegerency emphasizes that humans are the representatives of God on earth. Allah says in the Qur'an surah Al-Baqarah verse 30: "Verily I am going to make a Caliph on earth", and in surah Al-An'am verse 165: "And $\mathrm{He}$ is who has made you the rulers on earth". Therefore, human beings are trusted to manage and preserve all that God has on earth. 
b. Divine accountability. This principle illustrates that every human being will be held accountable on the day of vengeance for what he has done in his entire life. Responsibility to God is the basis for all Muslim actions, as well as for Islamic organizations. Several verses in the Qur'an explain the principle, two of which are surah Al-Zalzalah verse 7: "Whoever does good even in the small deed, undoubtedly he will see (the impact)" and surah An-Nisa verse 86: "Verily Allah reckons everything".

c. Enjoining good and forbidding evil. This principle is found in surah At-Taubah verse 71: "And those who believe, men and women, some of them (are) helpers of others. They enjoin what is right, prevent the evil." This responsibility covers all aspects of the life of Muslims.

According to Maali et al. (2006), the CSR disclosure by sharia banks has three general objectives: (1) to demonstrate compliance with Islamic principles, especially the matters or transactions related to other parties; (2) to show how the operations of the business affect the surrounding community; and (3) to help Muslims carry out their religious orders. These three objectives illustrate that CSR disclosure is not limited to activities related to social activities, such as donations or assistance to the needy, but also related to the daily activities of sharia banks which are associated to the Islamic principles.

The disclosure of CSR by sharia banks significantly varies. The variation is affected by the relevant public influence and good governance mechanism of the sharia supervisory board (Farook et al., 2011). Further research results by Farook et al. (2011) shows the degree of social and political freedom and the proportion of investment account deposits with total assets as a significant determinant of the CSR disclosure of sharia bank. Therefore, the CSR disclosure of sharia banking plays an important role by providing information related to the ethical responsibility of the organization or corporation to stakeholders and assisting them in the decision making (Hassan \& Harahap, 2010). In addition, CSR disclosure also has an effect on enhancing the image of Islamic financial institutions so that sharia banks can compete globally, especially with conventional banks.

\section{Islamic Social Reporting (ISR) Index}

A sharia framework is necessary for the process of constructing ISR which fulfills the accountability and transparency aims as a type of relationships between humans and God, humans and other humans, as well as humans and nature. In line with the more increasing number of CSR in Islamic context, there is also an increase in the willingness to create sharia social reports (Islamic Social Reporting-ISR). There are two matters needed to be disclosed in the Islamic perspective: full disclosure and social accountability. The social accountability concept is related to the principles of full disclosure with the aim of fulfilling public needs for information. In the Islamic context, the society possesses rights to know varied information related to the organization's activities. This is conducted to view whether the company keeps doing its sharia activities and achieving its aims of exixtence (Baydoun \& Willet., 1997).

The research in the field of sharia CSR commonly uses the model of ISR index which is developed based on the standard of AAOIFI report and to be developed later by the next researchers (Haniffa, 2002); Maali et al., 2006; Othman, Thani, \& Ghani, 2009). Specifically, ISR index is the extension of social reporting which covers society's hope on not only the company's role in the economy, but also its role in the spiritual perspective (Haniffa, 2002). Besides, ISR index also emphasizes on the social justice related to the report about the environment, minority rights, and the employees.

ISR index groups its indicators based on the research conducted by Fitria and Hartati (Fitria \& Hartanti, 2010) which shows that investment and financing consist of 13 items; goods and services consist of 3 items; and employees consist of 8 items. The assessment was conducted using scoring with the value 0 if there was no disclosure related to the items, and the value 1 if there was a disclosure related to the items. When all items are revealed, the maximum value will be 24 .

\section{Global Reporting Initiative (GRI) Index}

GRI index refers to the guidance on Global Reporting Initiative 2011 (Global Reporting Initiative, 2011), which later the elements are chosen based on the prominence related only to the industrial work of banking. Generally, the disclosure indicators are the organization's profile and strategy, economic matters, environmental matters, and social matters. The assessment is conducted by scoring from $0-1$, in which 0 means there is no disclosure related to the items, and 1 means there is a disclosure of the items.

When the full disclosure is conducted of the 74 items, there will be the maximum value of 74 . In order to have the same standard CSR score in the assessment of ISR and GRI, it is necessary to count the index using the following formula.

$\operatorname{CSRI} j=\frac{\sum \times i j}{N j}$ 
where CSRIj is Corporate Social Responsibility Index of company j; $\sum X_{i j}$ is the number of items revealed by company $\mathrm{j}$; and $\mathrm{N} j$ is the number of items for company $\mathrm{j}$. Based on the measurement between ISR and GRI, a compilation of the two CSR measurements is necessary to be created as described in Table 2. The compilation here is about making a group of variables within which the variables of GRI are the same equal with ISR variables to prove the hypothesis.

Table 2. Compilation of CSR measurements

\begin{tabular}{ll}
\hline GRI & ISR \\
\hline Environment & Environment \\
Energy & Energy \\
Occupational Health and Safety & Occupational Health and Safety \\
Product & Product \\
Society's Involvement & Society's Involvement \\
General Information & General Information \\
& Sharia Activity \\
\hline
\end{tabular}

\section{Prior Research}

Company characteristics such as company size, industrial sector, profitability, corporate governance mechanisms, political, social and cultural factors appear to predominantly drive the CSR reporting agenda (Ali et al., 2017). Numerous studies have investigated the CSR disclosure of companies with Islamic business (Aribi \& Gao, 2010; Haniffa \& Hudaib, 2007; Hassan \& Harahap, 2010; Bassam Maali et al., 2006; Nobanee \& Ellili, 2016). For example, Haniffa and Hudaib (2007) conducted a longitudinal survey study on the annual reports of seven Islamic Financial Institutions (IFI) in four Gulf-Arab countries. The aim of the research is to know the effectiveness of sharia bank communications on their ethical identities, the differences in the communicated information (based on the information disclosed in their annual reports), and the ideal disclosure (i.e. disclosure of information considered important based on the sharia business framework). Their findings showed the falling far short of what will enable ethical and social communication in IFI, and thus have different reports. This indicates that communication by IFI is still minimal which is due to the lack of pressure from the stakeholders and also the keeping secret culture prevailing in the region.

CSR disclosure of Islamic banks generally grow in both Malaysia and Indonesia (Amran et al., 2017). However, the level of CSR disclosure of Islamic banks in Indonesia as measured by the AAOIFI index continues to be low; on that account, Islamic banks must provide broader information to disclose (Nugraheni \& Khasanah, 2019). According to Nugraheni and Khasanah (2019), Indonesian government must determine certain items that need to be disclosed by Islamic banks, considering that there are no specific CSR disclosure regulations for Islamic banks in Indonesia.

Anuar et al. (2004) provide the evidence supporting the assumption that Islam has an effect on the corporate's environmental reporting. They compared the sharia corporate environmental practices that conducted business in accordance with Islamic principles and the non-sharia corporate environmental practices that were operating in Malaysia. The result showed that sharia companies had higher rates in environmental reporting than non-sharia companies. They suggest that a higher level of environmental reporting amongst the sharia firms may reflect the companies' efforts to present the corporate reporting that embodies Islamic principles and overall environmental accountability. Maali et al. (2006) examine the influence of Islam in social reporting. Based on Islamic principles and Islamic ethical values, Maali et al. (2006) developed a benchmark for social disclosure and expected that sharia banks could apply the benchmark. However, the results indicated that the level of social disclosure by sharia banks was still far from the benchmark and there was a considerable variation in terms of voluntary social reporting in sharia banks.

Moreover, Aribi and Gao (2010) examines the influence of Islam on CSR disclosure by looking into the annual reports of 21 conventional financial institutions (CFI) and 21 Islamic financial institutions (IFI) operating in the Gulf region. The purpose of the study was to examine the influence of Islam on the disclosure of social responsibility in Islamic financial institutions (IFI). The results showed significant discrepancies in terms of disclosure between IFI and CFI, largely due to the fact that the disclosures made by IFI were mostly on religious and informational themes, reports of sharia supervisory boards, zakah and charitable contributions, and interestfree loans. Hassan and Harahap (2010) examine whether there is a discrepancy between the company social activities disclosed in the annual report of sharia banks and the CSR disclosure index that has been developed based on the framework of Islamic business ethics. This research was conducted by surveying the annual reports of seven sharia banks by using content analysis method to measure CSR disclosure volume. The results showed the overall average CSR disclosure index in which one of the seven sharia banks rated above average, but CSR issues were not a major concern for most sharia banks. 


\section{CSR disclosure in Islamic banks is better than conventional banks}

The existence of the recent global trends is related to CSR practices. Though it is more common to be conducted in mining and manufacturing companies, banking industry has started to include its social responsibility aspects in its annual report in a simple form. Fitria and Hartanti (2010) state that institutions holding the business based on sharia law are in nature referring to the philosophical aspects of Al-Quran and Sunnah which are used as the basic references for the actors in interacting with the environment and the others. Regarding the religious philosophy, it is believed that the existing relationships will be more sustainable compared to that the conventional patterns. In addition, Dusuki and Dar (2005) opine that in sharia banking, the social responsibility is closely relevant to be discussed because of the sharia factors which require the institutions to be operated based on morality, ethic, and social responsibility. Besides, it is also because of the principles of obeying Allah and His messengers and concerning public prominence including destruction and poverty avoidance.

The study results of Fitria and Hartanti (2010) show that conventional banks demonstrate better disclosures compared to sharia banks. Nobanee and Ellili (2016) also find that the level of company sustainability disclosure of conventional banks is higher than that of the sharia banks. Meanwhile, Anuar et al. (2004) provide supporting evidence that Islam has a crucial effect on the company environmental report. It showed that sharia companies noted a higher level of the environmental report compared to non-sharia companies. Maali et al. (2006) reveal that the level of social disclosure by sharia banks is still far from the standard. Moreover, there is a large variation in the matters of voluntary social reporting in sharia banks. Aribi and Gao (2011) find a significant difference in the matters of disclosure between IFI and CFIs. Most of the causes are the facts that IFI is related to religious theme and information, sharia supervision board report, zakah and alms, and free of interest loan. Based on the above descriptions, the hypothesis of this study are:

H1a: CSR disclosure on the environmental aspects of Islamic banks is better than that of conventional banks.

$\mathrm{H} 1 \mathrm{~b}$ :CSR disclosure on the energy aspect of Islamic banks is better than that of conventional banks.

H1c: CSR disclosure on the occupational health and safety aspect of Islamic banks is better than that of conventional banks

H1d:CSR disclosure on the product aspect of Islamic banks is better than that of conventional banks

H1e: CSR disclosure on the society's involvement aspect of Islamic bank is better than that of conventional banks H1f: CSR disclosure on the general information aspects of Islamic bank is better than that of conventional banks

\section{Research Method}

This study applied the quantitative approach. The data used in this study were secondary data. The data sources covered financing reports in sharia and conventional banking companies in 2011-2014 which included CSR data. The population of this study was all common sharia and conventional banks registered in Indonesia Central Bank in the period of 2011-2014. The sampling technique was done using purposive sampling to get representative samples based on the chosen criteria, namely: First, sharia and conventional banking companies registered in Indonesia Central Bank in the period of 2011-2014; second, the previously mentioned companies with sustainable release of financing annual reports in the period of 2011-2014; and, third, the previously mentioned companies with sustainable implementation of CSR disclosure in the period of 2011-2014. In measurement, CSR of conventional bank was measured with Global Reporting Initiative (GRI) Index, while CSR of sharia bank was measured using Islamic Social Reporting (ISR) Index.

Based on the criteria, the random samples of data taken consisted of five sharia banks and five conventional banks. Those five sharia banks were Sharia BRI, Sharia Bukopin, Sharia Mega, Sharia BCA, and Sharia Mandiri, and five conventional banks involved BRI, Bank Bukopin, Bank Mega, BCA, and Bank Mandiri. The total number of data was 40 (20 from sharia banks and another 20 from conventional banks).

The descriptive statistics such as Mean, Standard Deviation, and Standard Error Mean were calculated to show the main features of the data in the study. The statistics only provided a way to describe or summarize the data which later allowed the researcher to draw meaningful conclusions from them. The Independent Sample Ttest compares the mean values of two independent groups to check statistical evidence of whether the population from which the sample was drawn has different mean values (Malhotra \& Dash, 2011). In this study, the independent sample t-test was applied to determine whether there was a significant difference in the average value of Islamic banks and conventional banks. The level of significance $(\alpha)$ was set at 5 per cent.

\section{Result and Discussion}

The results of the descriptive statistics for CSR disclosure showed that almost all aspects of sharia bank indicated greater disclosure than those of conventional banks. Table 3 shows the descriptive statistics of CSR aspects including energy, occupational health and safety, products, and society involvement. 
The descriptive results on the environmental aspect of conventional banks recorded CSR disclosure average of 0.550 , higher than that of sharia banks, which was 0.000. Likewise, the disclosure of general information on conventional banks showed CSR disclosure average of 1,000, higher than that of sharia banks, which was 0.550 . Meanwhile, the energy disclosure average of sharia banks was 1.000 which was higher than that of conventional banks at only 0.60 . The disclosure on occupational health and safety aspect of sharia banks demonstrated an average of 0.7143 which was higher than that of conventional banks with only 0.40 . Furthermore, the disclosure on product aspect of sharia banks had an average of 1.000 which was higher than conventional banks with only 0.6567. Likewise, the disclosure of CSR in the aspect of society involvement of sharia bank had an average of 0.75 , higher than that of conventional banks which was only 0.4364 .

Table 3. Descriptive Statistics of CSR Disclosure Aspects

\begin{tabular}{|c|c|c|c|c|c|}
\hline Banks & & $\mathrm{N}$ & Mean & $\begin{array}{c}\text { Std. } \\
\text { Deviation }\end{array}$ & Std. Error Mean \\
\hline Environment & $\begin{array}{l}\text { Conventional } \\
\text { Sharia }\end{array}$ & $\begin{array}{l}20 \\
20\end{array}$ & $\begin{array}{l}.5500 \\
.0000\end{array}$ & $\begin{array}{l}.13079 \\
.00000\end{array}$ & $\begin{array}{l}.02924 \\
.00000\end{array}$ \\
\hline Energy & $\begin{array}{l}\text { Conventional } \\
\text { Sharia }\end{array}$ & $\begin{array}{l}20 \\
20\end{array}$ & $\begin{array}{c}.6000 \\
1.0000\end{array}$ & $\begin{array}{l}.20520 \\
.00000\end{array}$ & $\begin{array}{l}.04588 \\
.00000\end{array}$ \\
\hline Occupational health and safety & $\begin{array}{l}\text { Conventional } \\
\text { Sharia }\end{array}$ & $\begin{array}{l}20 \\
20\end{array}$ & $\begin{array}{l}.4000 \\
.7143\end{array}$ & $\begin{array}{l}.07281 \\
.38220\end{array}$ & $\begin{array}{l}.01628 \\
.08546\end{array}$ \\
\hline Product & $\begin{array}{l}\text { Conventional } \\
\text { Sharia }\end{array}$ & $\begin{array}{l}20 \\
20\end{array}$ & $\begin{array}{l}.6567 \\
1.0000\end{array}$ & $\begin{array}{l}.04472 \\
.00000\end{array}$ & $\begin{array}{l}.01000 \\
.00000\end{array}$ \\
\hline Society involvement & $\begin{array}{l}\text { Conventional } \\
\text { Sharia }\end{array}$ & $\begin{array}{l}20 \\
20\end{array}$ & $\begin{array}{l}.4364 \\
.7500\end{array}$ & $\begin{array}{l}.09139 \\
.00000\end{array}$ & $\begin{array}{l}.02043 \\
.00000\end{array}$ \\
\hline General informaton & $\begin{array}{l}\text { Conventional } \\
\text { Sharia }\end{array}$ & $\begin{array}{l}20 \\
20\end{array}$ & $\begin{array}{l}1.0000 \\
.5500\end{array}$ & $\begin{array}{l}.00000 \\
.10260 \\
\end{array}$ & $\begin{array}{l}.00000 \\
.02294\end{array}$ \\
\hline
\end{tabular}

A summary of the disclosures made by both sharia banks and conventional banks is presented in Table 4 . It shows that all sample reports provide CSR disclosure. The overall level of CSR disclosure of sharia banks is greater than that of conventional banks. The average CSR disclosure based on the compilation of aspects expressed by sharia banks was 4.014 compared to conventional banks which was 3.643. The statistical results showed that the differences between the two groups were statistically significant. To determine the toughness of the results, the independent $t$-test was performed to support the findings with the significant level 0.05. However, the differences in disclosure rates varied between the various themes among the two groups.

Table 4. Comparison of CSR Disclosure between Sharia and Conventional Banks

\begin{tabular}{lccrr}
\hline CSR Aspects & $\begin{array}{c}\text { Conventional Banks } \\
(\text { Mean })\end{array}$ & $\begin{array}{c}\text { Sharia Banks } \\
\text { (Mean) }\end{array}$ & $t$-test & p-value \\
\hline Environment & 0.550 & 0.000 & -5.818 & 0.000 \\
Energy & 0.600 & 1.000 & -5.099 & 0.000 \\
Occupational health and safety & 0.400 & 0.714 & 3.612 & 0.001 \\
Product & 0.657 & 1.000 & -5.865 & 0.000 \\
Society involvement & 0.436 & 0.750 & -5.846 & 0.000 \\
General information & 1.000 & 0.550 & -6.009 & 0.000 \\
Total & 3.643 & 4.014 & & \\
Significant at $\alpha=5 \%$ & & & & \\
\hline
\end{tabular}

The CSR disclosure comparative results based on the compilation of results showed that sharia banks demonstrated greater disclosure in almost all aspects of CSR such as energy, occupational health and safety, product, and society involvement. Meanwhile, in the environment and general information aspects, conventional banks proved higher.

As evident from Table 4, $t$-value was -5.818 (p-value was 0.000) with level of significance 5 per cent. It signifies that variation exists between sharia and conventional banks with respect to the percentage of CSR disclosure. Thus, it depicts that sharia banks provide significantly more CSR disclosures in contrast to conventional banks in terms of environmental aspect. When it is viewed from the mean of the sharia bank which was 0.000 , lower than the mean of conventional banks that was 0.550, it indicates that CSR disclosure on the environmental aspect of conventional banks is higher than that of sharia banks, so H1a is rejected.

Furthermore, the test results of CSR disclosure on energy aspect using $t$-test was -5.099 , with p-value 0.000 . Since $0.000<0.05$, it can be said that there is a significant difference in CSR disclosure in terms of energy between conventional banks and sharia banks. Then, the sharia banks' disclosure level on energy aspect was higher 
than that of conventional banks $(1.000>0.600)$, indicating that CSR disclosure in energy aspect of sharia bank is better than that of conventional banks, so $H 1 b$ is supported.

In the occupational health and safety aspect, the $t$-test result obtained was 3.612, with p-value 0.001. Since $0.001<0.05$, it can be said that there is a significant difference in CSR disclosure in terms of occupational health and safety between conventional banks and sharia banks. When it is viewed from the mean of sharia banks which was 0.714 , that was higher than the mean of the conventional banks at 0.400 . Hence, it can be concluded that CSR disclosure on the aspect of occupational health and safety in sharia banks is higher than and significantly different from that of conventional banks. As a result, H1c is supported. Likewise, H1d is supported, with the mean of sharia banks was 1.000 which was higher than the mean of conventional banks at 0.657 .

Moreover, the CSR disclosure test results on the society involvement aspect obtained the $t$-test score 5.846, with p-value 0.000 . Since $0.000<0.05$, it can be said that there is a significant difference in CSR disclosure in terms of society involvement between conventional banks and sharia banks. In addition, the mean of sharia banks was 0.750 which was higher than the mean of the conventional bank that was 0.436 . This shows that CSR disclosure on the aspect of society involvement of sharia banks is higher than and significantly different from that of conventional banks. Consequently, Hle is supported.

However, the CSR disclosure test results on general information aspect obtained from $t$-test was -6.009 , with p-value 0.000 . Since $0.000<0.05$, it means that there is a significant difference in CSR disclosure in terms of general information between conventional banks and sharia banks. The mean of sharia banks was 0,550 which was lower than the mean of the conventional banks that was 1.000. That indicates that the disclosure of CSR on general information aspects of conventional banks is higher than and significantly different from sharia banks, so $H 1 f$ is rejected.

Based on the results of CSR disclosure comparison test between sharia and conventional banks, it can be seen that there are significant differences in CSR disclosure on the aspects of environment, energy, occupational health and safety, product, society involvement, and general information. Nevertheless, the test on each aspect of CSR disclosure found that not all the scores of the CSR aspects of sharia banks are higher than those of conventional banks. Environmental and general information aspects of conventional banks are wider than those of sharia banks. As for the aspects of energy, occupational health and safety, product, and society involvement in sharia banks scored higher than those in conventional banks. This makes the basis for sharia bank managements to further improve their mutual interaction with the environment. Given that the philosophical basis of sharia banking practices is religious, it is believed that the existing relationships will be more sustainable than if it is based on the conventional patterns. Dusuki and Dar (Dusuki \& Dar, 2005) state that in sharia banking, social responsibility is very relevant to be discussed considering three factors. First, sharia banking is based on sharia principles that require it to operate on moral, ethical, and social responsibility grounds. Another principle is obedience to the command of Allah and the Caliph, and the last principle is of public interest, involving the avoidance of destruction and poverty.

The results of this study indicate that CSR disclosure of sharia banks in the aspects of energy, occupational health and safety, product, and society involvement is higher or better than the disclosure on the same aspects of conventional banks. This study is in line with the study of Anuar et al. (2004), which shows that sharia corporates have higher level of social reporting than non-sharia corporates. Also, Maali et al. (2006) indicate that the level of social disclosure by sharia banks is still far from the benchmark and there is considerable variation in voluntary social reporting in sharia banks. In addition, Chintaman (2014) find that Islamic banks are more innovative in conducting various types of CSR activities.

The study also supports Fitria and Hartanti's (2010) research which reveals that conventional banks have better disclosures than sharia banks in environment and general information aspects. This is because conventional banks are much longer standing compared to sharia banks, so the conventional bank's closeness with the environment is greater. Additionally, the awareness of the environment around the banks is also greater, including pollution control, greening programs, conservation of natural resources, and other environmental conservation programs. This study also confirms the research conducted by El-Halaby and Hussainey (2015) who argue that the CSR disclosure level of Islamic banks around the world is very low.

In the case of general information, conventional banks are more famous in public, so conventional banks are more open to share general information, such as disclosing the corporate objectives/policies in general related to CSR to the public and information related to CSR in the form of incidental programs or other programs.

\section{Conclusion}

The test result using compilation of per-aspect approach showed that there were significant differences in CSR disclosure in the aspects of environment, energy, occupational health and safety, product, community involvement, and general information between conventional banks and sharia banks. CSR disclosure of sharia banks in the aspects of energy, occupational health and safety, product, and society involvement rates higher or better than that 
of conventional banks. This study is in line with the study by Anuar et al. (2004). Meanwhile, CSR disclosure of conventional banks in the aspects of environment and general information scores higher than that of sharia banks; this study thereby is in line with the studies of Maali et al. (2006) and Fitria and Hartanti (2010).

This study has limitations, among others is that the data used in this study were only secondary data that could not obtain the details of the existing data quality. Moreover, the number of study samples was limited to only large commercial banks, and there was no sample from the rural bank.

Due to the limitations of this study in compiling the variable aspects of GRI and ISR index, it is suggested for further study to carry out a more detailed analysis in compiling in order to obtain the better data. Since this study only employed the secondary data, it is therefore preferable for further study to combine them with the primary data to know precisely the quality of the data disclosed by each bank.

\section{References}

Al-Shamali, F. A., Sharif, A., \& Irani, Z. (2013). Islamic banking reinterpretation of the stakeholder theory. Oman Chapter of Arabian Journal of Business and Management Review, 3(2), 63-71.

Albaity, M., \& Ahmad, R. (2008). Performance of Syariah and Composite Indices : Evidence From Bursa Malaysia. Asian Academy of Management Journal of Accounting and Finance, 4(1), 23-43.

Ali, W., Frynas, J. G., \& Mahmood, Z. (2017). Determinants of Corporate Social Responsibility (CSR) Disclosure in Developed and Developing Countries: A Literature Review. Corporate Social Responsibility and Environmental Management, 24(4), 273-294. https://doi.org/10.1002/csr.1410

Amran, A., Fauzi, H., Purwanto, Y., Darus, F., Yusoff, H., Zain, M. M., Naim, D. M. A., \& Nejati, M. (2017). Social responsibility disclosure in Islamic banks: a comparative study of Indonesia and Malaysia. Journal of Financial Reporting and Accounting, 15(1), 99-115. https://doi.org/10.1108/JFRA-01-2015-0016

Anuar, H., Sulaiman, M., \& Ahmad, N. (2004). Environmental reporting of Shariah approved companies in Malaysia. Proceeding of International Accounting Conference II.

Aribi, Z. A., \& Gao, S. (2010). Corporate social responsibility disclosure: A comparison between Islamic and conventional financial institutions. Journal of Financial Reporting and Accounting, 8(2), 72-91. https://doi.org/10.1108/19852511011088352

Aribi, Z. A., \& Gao, S. S. (2011). Narrative disclosure of corporate social responsibility in Islamic financial institutions. Managerial Auditing Journal, 27(2), 199-222. https://doi.org/10.1108/02686901211189862

Baydoun, N., \& Willet., R. (1997). Islam and accounting: Ethical issues in the presentation of financial information. Accounting, Commerce and Finance: The Islamic Perspective Journal, 1(1), 1-25.

Beetham, D. (2013). The Legitimation of Power(2nd ed.). Palgrave Macmillan.

Bhatia, A., \& Makkar, B. (2019). CSR disclosure in developing and developed countries: a comparative study. Journal of Global Responsibility, 11(1), 1-26. https://doi.org/10.1108/jgr-04-2019-0043

Bowen, H. R. (1953). Social Responsibilities of the Businessman. Harper.

Burke, L., \& Logsdon, J. M. (1996). How corporate social responsibility pays off. Long Range Planning, 29(4), 495502. https://doi.org/10.1016/0024-6301(96)00041-6

Chintaman, S. A. (2014). A Comparative Study of CSR Practices of Islamic Banks and Conventional Banks in GCC Region. Journal of Islamic Banking and Finance, 2(1), 1-21.

Clarkson, M. B. E. (1995). A stakeholder framework for analyzing and evaluating corporate social performance. Academy of Management Review, 20(1), 92-117. https://doi.org/10.5465/AMR.1995.9503271994

Davies, P. W. F. (1997). Business Philosophy: Searching for an Authentic Role. In P. W. F. Davies (Ed.), Current Issues in Business Ethics. Routledge.

Deegan, C. (2002). The legitimising effect of social and environmental disclosures - a theoretical foundation. Accounting, Auditing \& Accountability Journal, 15(3), 282-311. https://doi.org/10.1108/09513570210435852

Deegan, C., \& Blomquist, C. (2006). Stakeholder influence on corporate reporting: An exploration of the interaction between WWF-Australia and the Australian minerals industry. Accounting, Organizations and Society, 31(4-5), 343-372. https://doi.org/10.1016/j.aos.2005.04.001

Dusuki, A. W. (2008). What does Islam say about corporate social responsibility? Review of Islamic Economics, 
12(1), 5-28.

Dusuki, A. W., \& Dar, H. (2005). Stakeholders' perceptions of corporate social responsibility of Islamic banks: evidence from Malaysian economy. International Conference on Islamic Economics and Finance.

El-Halaby, S., \& Hussainey, K. (2015). The determinants of social accountability disclosure: Evidence from islamic banks around the world. International Journal of Business, 20(3), 202-223.

Faradisty, A., Hariyani, E., \& Wiguna, M. (2019). The effect of corporate social responsibility, profitability, independent commissioners, sales growth and capital intensity on tax avoidance. Journal of Contemporary Accounting, 1(3), 153-160. https://doi.org/10.20885/jca.vol1.iss3.art3

Farook, S. (2007). On corporate social responsibility of Islamic financial institutions. Islamic Economic Studies, 15(1), 31-46. https://doi.org/10.1002/csr.132

Farook, S., Hassan, M. K., \& Lanis, R. (2011). Determinants of corporate social responsibility disclosure: the case of Islamic banks. Journal of Islamic Accounting and Business Research, 2(2), 114-141. https://doi.org/10.1108/17590811111170539

Fitria, S., \& Hartanti, D. (2010). Islam dan Tanggung Jawab Sosial : Studi Perbandingan Pengungkapan Berdasarkan Global Reporting Initiative Indeks Dan Islamic Social Reporting Indeks. Simposium Nasional Akuntansi XIII.

Fombrun, C. J., Gardberg, N. A., \& Barnett, M. L. (2000). Opportunity Platforms and Safety Nets: Corporate Citizenship and Reputational Risk. Business and Society Review, 105(1), 85-106.

Friedman, M. (1962). Capitalism and Freedom. University of Chicago Press.

Garriga, E., \& Melé, D. (2004). Corporate Social Responsibility Theories: Mapping the Territory. Journal of Business Ethics, 53(1/2), 51-71. https://doi.org/10.1787/9789264122352-de

Global Reporting Initiative. (2011). Sustainability Reporting Guidelines version 3.1 Amsterdam, The Netherlands. https://doi.org/https://www.globalreporting.org/resourcelibrary/G3-Guidelines-Incl-TechnicalProtocol.pdf

Gray, R., Kouhy, R., \& Lavers, S. (1995a). Constructing a research database of social and environmental reporting by UK companies. Accounting, Auditing \& Accountability Journal, 8(2), 78-101.

Gray, R., Kouhy, R., \& Lavers, S. (1995b). Corporate social and environmental reporting: a review of the literature and a longitudinal study of UK disclosure. Accounting, Auditing \& Accountability Journal, 8(2), 47-77. https://doi.org/10.1108/09513579510146996

Greenfield, W. M. (2004). In the name of corporate social responsibility. Business Horizons, 47(1), 19-28. https://doi.org/10.1016/j.bushor.2003.11.004

Guthrie, J., \& Parker, L. D. (1989). Corporate social reporting: A rebuttal of legitimacy theory. Accounting and Business Research, 1976), 343-352. https://doi.org/10.1080/00014788.1989.9728863

Haniffa, R. (2002). Social reporting disclosure: an Islamic perspective. Indonesian Management \& Accounting Research, 1(2), 128-146.

Haniffa, R., \& Hudaib, M. (2007). Exploring the ethical identity of Islamic Banks via communication in annual reports. Journal of Business Ethics, 76(1), 97-116. https://doi.org/10.1007/s10551-006-9272-5

Hassan, A., \& Harahap, S. S. (2010). Exploring corporate social responsibility disclosure : the case of Islamic banks. International Journal of Islamic and Middle Eastern Finance and Management, 3(3), 203-227. https://doi.org/10.1108/17538391011072417

Husted, B. W. (2003). Governance choices for corporate social responsibility: to contribute, collaborate or internalize? Long Range Planning, 36(5), 481-498. https://doi.org/10.1016/S0024-6301(03)00115-8

Johnson, H. H. (2003). Does it pay to be good? Social responsibility and financial performance. Business Horizons, 46(6), 34-40.

Keller, N. (1994). Reliance of the Traveller: A Classic Manual of Islamic Sacred Law by Ibn Naqib Al-Masri. Amana, Beltsville, MD.

Lantos, G. P. (2001). The boundaries of strategic corporate social responsibility. Journal of Consumer Marketing, 18(7), 595-630. https://doi.org/10.1108/07363760110410281 
Lantos, G. P. (2002). The ethicality of altruistic corporate social responsibility. Journal of Consumer Marketing, 19(3), 205-230. https://doi.org/10.1108/07363760210426049

Maali, B., Casson, P., \& Napier, C. (2006). Social reporting by Islamic banks. ABACUS, 42(2), $266-289$. https://doi.org/10.1111/j.1468-4497.2006.00200.x

Maali, Bassam, Casson, P., \& Napier, C. (2006). Social reporting by Islamic banks. Abacus, 42(2), $266-289$.

Maignan, I., \& Ferrell, O. C. (2004). Corporate social responsibility and marketing: An integrative framework. Journal of the Academy of Marketing Science, 32(1), 3-19. https://doi.org/10.1177/0092070303258971

Malhotra, N. K., \& Dash, S. (2011). Marketing research, an applied orientation. Pearson.

Moir, L. (2001). What do we mean by corporate social responsibility? Corporate Governance: The International Journal of Business in Society, 1(2), 16-22. http://www.iso.org/iso/home/standards/iso26000.htm

Ness, K. E., \& Mirza, A. M. (1991). Corporate social disclosure: A note on a test of agency theory. British Accounting Review, 23(3), 211-217. https://doi.org/10.1016/0890-8389(91)90081-C

Nobanee, H., \& Ellili, N. (2016). Corporate sustainability disclosure in annual reports: Evidence from UAE banks: Islamic versus conventional. Renewable and Sustainable Energy Reviews, 55(March 2016), 1336-1341. https://doi.org/10.1016/j.rser.2015.07.084

Nugraheni, P., \& Khasanah, E. N. (2019). Implementation of the AAOIFI index on CSR disclosure in Indonesian Islamic banks. Journal of Financial Reporting and Accounting, 17(3), 365-382. https://doi.org/10.1108/JFRA-02-2018-0013

Othman, R., Thani, A. M., \& Ghani, E. K. (2009). Determinants of Islamic social reporting among top shariah approved companies in bursa Malaysia. Research Journal of International Studies, 12(12), 4-20.

Quester, P. G., \& Thompson, B. (2001). Advertising and promotion leverage on arts sponsorship effectiveness. Journal of Advertising Research, 41(1), 33-47. https://doi.org/10.2501/JAR-41-1-33-47

Rice, G. (1999). Islamic ethics and the implications for business. Journal of Business Ethics, 18(4), 345-358.

Sallam, H., \& Hanafy, A. (1988). Employee and employer: Islamic perception. Proceeding of the Seminar on Islamic Principles of Organizational Behaviour.

Tinker, T. (2004). The Enlightenment and its discontents: Antinomies of Christianity , Islam and the calculative sciences. Accounting, Auditing \& Accountability Journal, 17(3), 442-475. https://doi.org/10.1108/09513570410545812

Williamson, D., \& Lynch-Wood, G. (2008). Social and environmental reporting in UK company law and the issue of legitimacy. Corporate Governance, 8(2), 128-140. https://doi.org/10.1108/14720700810863760

Windsor, D. (2001). The future of corporate social responsibility. International Journal of Organizational Analysis, g(3), 225-256.

Yamak, S., \& Süer, Ö. (2005). State as a stakeholder. Corporate Governance, 5(2), 111-120. https://doi.org/10.1108/14720700510562695

Zaher, T. S., \& Hassan, M. K. (2001). A Comparative Literature Survey of Islamic Finance and Banking. Financial Markets, Institutions \& Instruments, 10(4), 155-199. https://doi.org/doi: 10.1111/1468-0416.00044 